\title{
PEMBATASAN PARTAI POLITIK PESERTA PEMILIHAN UMUM DALAM PERSPEKTIF DEMOKRASIARYA
}

\author{
Achmad Zakaria ${ }^{1}$ \\ Magister Hukum Fakultas Hukum Universitas Jenderal Soedirman \\ Email: arya_achmadzakaria@yahoo.com
}

\begin{abstract}
Political parties have a position and role is very important in any democratic system. Restrictions on both parties and the electoral threshold parlimentary threshold is one element in a multi party system and the proportional representation system (proportional) with a certain percentage of the total national vote, it is certainly a clash of democracy on the one hand saying, but on the other hand is limited. This study aimed to identify and analyze the setting restrictions on political parties participating in the elections in the perspective of democracy. In addition, to analyze the restrictions on political parties participating in setting the general election in Act No. 8 of 2012 on the Election of the constitutional rights in the Constitution of 1945, also used normative juridical research method.

The study states that, setting restrictions on political parties participating in the elections in the perspective of democracy in Law No. 8 of 2012 on the Election of Members of DPR, DPD and DPRD stipulated in Article 8 paragraph (1), Article 8 (2) and Article 208 of Law No. 8 of 2012 on the Election of Members of DPR, DPD and DPRD. Settings must meet the threshold of votes of at least 3.5\% (three point five percent) of the total valid votes nationally to be included in the determination of the number of seats for the DPR, Provincial DPRD and regency / city violated the rights of democracy. Thus after the Constitutional Court Decision No. 52 / PUU-X / 2012, Article 208 which regulates the whole phrase "Provincial DPRD and regency / city" does not have binding legal force, thus only bind the Parliament alone. Restrictions on participants in the elections through a system of thresholds in Law No. 8 of 2012 on General Election violate constitutional rights that exist in part in Article 28, Article 28C paragraph (2), Article 28D paragraph (1), Article $28 \mathrm{E}$ paragraph (3), Article 28H (2) and Article 281 paragraph (2) of the 1945 Provisions of Article 208 of Law $8 / 2012$ and the explanation is aimed at simplifying party naturally.
\end{abstract}

Keyword: Democracy, Limitation, Politic Party

\begin{abstract}
Abstrak
Partai politik mempunyai posisi dan peranan yang sangat penting dalam setiap sistem demokrasi. Pembatasan partai baik electoral treshold dan parlimentary treshold adalah salah satu unsur dalam sistem kepartaian multipartai dan sistem perwakilan berimbang (proporsional) dengan persentase tertentu dari total suara nasional, hal ini tentunya menjadi benturan disatu sisi dikatakan demokrasi, namun di sisi lain dibatasi. Penelitian ini ditujukan untuk mengetahui dan menganalisis pengaturan pembatasan partai politik peserta pemilihan umum dalam perspektif demokrasi. Juga untuk menganalisis pengaturan pembatasan partai politik peserta pemilihan umum dalam Undang-Undang Nomor 8 Tahun 2012 tentang Pemilihan Umum terhadap hak konsitusional dalam Undang-Undang Dasar 1945, dengan metode penelitian yuridis normatif.

Hasil penelitian menyatakan, pengaturan pembatasan partai politik peserta pemilihan umum dalam perspektif demokrasi dalam UU No. 8 Tahun 2012 tentang Pemilihan Umum Anggota DPR, DPD, dan DPRD diatur dalam Pasal 8 ayat (1), Pasal 8 ayat (2) dan Pasal 208. Pengaturan keharusan memenuhi ambang batas perolehan suara sekurang-kurangnya 3,5\% dari jumlah suara sah secara nasional untuk diikutkan dalam penentuan perolehan kursi anggota DPR, DPRD provinsi, dan DPRD kabupaten/kota melanggar hak demokrasi. Putusan MK No. 52/PUU-X/2012, Pasal 208 mengatur sepanjang frasa"DPRD provinsi, dan DPRD kabupaten/kota" tidak mempunyai kekuatan hukum mengikat, dengan demikian hanya mengikat DPR saja. Pembatasan peserta pemilu melalui sistem ambang batas dalam UU No. 8 Tahun 2012 Tentang Pemilihan Umum melanggar sebagian hak konstitusi yang ada dalam Pasal 28, Pasal 28C ayat (2), Pasal
\end{abstract}

1 Mahasiswa Magister Hukum Fakultas Hukum Universitas Jenderal Soedirman 
28D ayat (1), Pasal 28E ayat (3), Pasal 28H ayat (2) dan Pasal 281 ayat (2) UUD 1945. Ketentuan Pasal 208 UU 8/2012 dan Penjelasannya bertujuan untuk penyederhanaan kepartaian secara alamiah.

Kata Kunci: Pembatasan, Partai Politik dan Demokrasi

\section{PENDAHULUAN}

Partai politik merupakan pilar yang sangat penting untuk diperkuat derajat pelembagaannya (the degree of institutionalization) dalam setiap sistem politik yang demokratis. Schattscheider menyatakan pula, "Modern democracy is unthinkable save in terms of the parties". ${ }^{2}$ Sejarah menunjukkan bahwa pembatasan tujuannya adalah untuk mengeliminasi partai-partai yang sesungguhnya tidak diinginkan kehadirannya. Proses itu kemudian berkembang di Indonesia menjadi lebih luas lagi, sehingga threshold menjadi bentuk pembatasan untuk mengikuti pemilu berikutnya bagi partai yang telah ikut pemilu, tujuannya adalah untuk mengurangi jumlah Parpol. Hal ini sangat merugikan hak kostitusional para partai politik calon peserta pemilu menurut pendapat penulis, padahal para calon peserta pemilu telah memenuhi syarat sebagai peserta pemilu sebagaimana yang ditentukan oleh Pasal 7 ayat (1) UU Nomor 12 Tahun 2003. Pembatasan tersebut ternyata juga ada dalam Undang-Undang Nomor 8 Tahun 2012 tentang Pemilihan Umum.

Berdasarkan Pasal 28, Pasal 28C ayat (2), Pasal 28D ayat (1), Pasal 28E ayat (3), Pasal 28H ayat (2) dan Pasal 281 ayat (2) UUD 1945, secara konstitusional setiap orang telah diberikan hak yang sangat mendasar, berupa kemerdekaan berserikat, berkumpul, mengeluarkan pendapat, memperjuangkan haknya secara kolektif, tanpa diskriminatif atas dasar apapun juga, bersamaan kedudukannya didepan hukum tanpa ada kecualinya, untuk membangun masyarakat, bangsa dan negara.

Konstitusi yang berlaku yakni UUD 1945 telah cukup memuat jaminan dan rambu-rambu konstitusional tentang Pemilu, ditambah lagi dengan ketentuan tentang Hak Asasi Manusia (HAM) yang sangat erat kaitannya dengan pemilu. Oleh karena itu, Undang-Undang Pemilu sebagai undang-undang organik betul-betul harus memperhatikan jaminan konstitusional tentang pemilu yang sudah ditentukan oleh UUD 1945.

Undang Nomor 8 Tahun 2012 Tentang Pemilihan Umum mengatur adanya pembatasan partai peserta pemilu baik melalui parlementary treshold maupun electoral treshold. Namun apakah pembatasan tersebut melanggar hak asasi manusia khususnya kebebasan berserikat dan berkumpul, ataupun hak memilih dan dipilih. Bukankah suatu partai dipilih atau tidak dipilih tergantung rakyat yang memilih, bukan ditentukan oleh seberapa besar partai tersebut dipilih tahun lalu. Hal inilah yang menjadi suatu legal gap atau permasalahan hukum. Di satu sisi HAM mengamanatkan untuk bebas berserikat dan berkumpul, berhak untuk dipilih dan memilih, namun mengapa terjadi pembatasan.

2 Jimly Asshiddiqie, 2006, Kemerdekaan Berserikat, Pembubaran Partai Politik dan Mahkamah Konstitusi, Konstitusi Press, Jakarta, hal. 53 
Indonesia adalah Negara yang sedang menerapkan demokrasi, selain itu Indonesia juga menjamin hak-hak demokrasi, namun demikian terjadi pula pembatasan partai politik peserta pemilhan umum. Oleh karena itu bagaimanakah pengaturan pembatasan partai politik peserta pemilihan umum dalam perspektif demokrasi. Berdasarkan hal tersebut, maka penelitian ini diharapkan dapat memberikan acuan deskripsi mengenaai hak kebebasan berpolitik di Indonesia.

\section{RUMUSAN MASALAH}

Berdasarkan latar belakang masalah di atas, dirumuskan masalah tersebut sebagai berikut: Pertama, bagaimanakah pengaturan pembatasan partai politik peserta pemilihan umum dalam perspektif demokrasi, Kedua, apakah pengaturan pembatasan partai politik peserta pemilihan umum dalam Undang-Undang Nomor 8 Tahun 2012 tentang Pemilihan Umum melanggar hak konsitusional dalam Undang-Undang Dasar 1945.

\section{METODE PENELITIAN}

Metode Pendekatan yang digunakan adalah Yuridis Normatif, dengan jenis data yaitu data primer dan data sekunder. Data yang diperoleh dianalisa secara kualitatif.

\section{PEMBAHASAN}

Pengaturan Pembatasan Partai Politik Peserta Pemilihan Umum Dalam Perspektif Demokrasi

Dalam Undang-Undang Nomor 8 Tahun 2012 tentang Pemilihan Umum Anggota DPR, DPD, dan DPRD Perwakilan Daerah mengisyaratkan Ambang batas 3,5 persen berlaku menyeluruh dari pemilihan DPR, DPD, DPRD (provinsi, kabupaten dan kota), hal ini tentunya akan melahirkan beberapa masalah yang akan terjadi, pertama, jika sekiranya PT 3,5 persen di belakukan surut samapai pada tingkat lokal maka kemungkinan sulit bagi partai politik di daerah untuk memenuhi ketentuan ini, dan mungkin tidak ada satu kader partai pun yang mampu duduk di kursi parlemen sebab, energi dan daya mobilisasi politik partai di tingkat lokal tidak terlalu besar. Hal ini bisa di lihat pada komposisi perolehan suara partai di tingkat lokal pada pemilu tahun 2009 lalu. Kedua, logika pemberlakuan PT secara nasional ini akan menyebabkan disproporsionalitas dalam pemilu. Sebab, jikalau partai memperoleh dukungan di daerah namun pada tingkat nasional tidak memenuhi kecukupan suara dengan standarisasi ambang batas 3,5 persen dari total suara secara nasional maka otomatis kursi di daerah hilang (wasted). Ketiga, PT 3,5 persen akan menyebabkan jumlah kursi di DPRD Kabupaten/ Kota tidak akan terbagi habis apalagi jika jumlah partainya banyak dan kemampuan perolehan ratarata suara dalam pemilu sama. Kalaupun terdapat beberapa partai yang perolehan suaranya melebihi ambang batas yang di tentukan tetap saja akan menyisahkan jumlah kursi yang tidak terisi, hal ini bertentangan dengan asas demokrasi perwakilan yang menghendaki terlembaganya partisipasi dan aspirasi bagi setiap anggota masyarakat.

Akibat hukum pasca putusan Mahkamah Konstitusi yaitu 22 partai politik tidak bisa menjadi peserta pemilihan umum tahun 2014, karena Mahkamah Konstitusi hanya menghapus frasa: "yang tidak memenuhi ambang batas, atau partai politik baru". Sedangkan syarat yang memberatkan partai politik baru tidak dihapus oleh Mahkamah 
Konstitusi. Persyaratan partai politik peserta pemilihan umum tahun 2014 pasca putusan Mahkamah Konstitusi bertentangan dengan hak konstitusional yang dijamin dalam pasal 28 huruf $\mathrm{C}$ ayat (2), pasal 28 huruf d ayat (1), ayat (3), pasal 28 huruf I ayat (2) UUD 1945, karena hanya 12 partai politik yang lolos menjadi peserta pemilu tahun 2014. 9 partai politik yang lolos menjadi peserta pemilu adalah partai parlemen, 2 partai politik baru, dan 1 partai politik yang tidak memiliki kursi di DPR pada pemilu tahun 2009.

Pasca Putusan Mahkamah Konstitusi No. 52/PUU-X/2012 sikap KPU menjadi serba salah. Pada tanggal 7 September 2012, Komisi Pemilihan Umum mengumumkan daftar 46 partai politik yang telah mendaftarkan diri untuk mengikuti Pemilu 2014, dimana beberapa partai diantaranya merupakan partai politik yang baru pertama kali mengikuti pemilu ataupun baru mengganti namanya. 9 partai lainnya merupakan peserta Pemilu 2009 yang berhasil mendapatkan kursi di DPR periode 2009-2014. Pada tanggal 10 September 2012, KPU meloloskan 34 partai yang memenuhi syarat pendaftaran minimal 17 buah dokumen.

Selanjutnya pada tanggal 28 Oktober 2012 , KPU mengumumkan 16 partai yang lolos verifikasi administrasi dan akan menjalani verifikasi faktual. Pada perkembangannya, sesuai dengan keputusan Dewan Kehormatan Penyelenggara Pemilihan Umum, verifikasi faktual juga dilakukan terhadap 18 partai yang tidak lolos verifikasi administrasi. Hasil dari verifikasi faktual ini ditetapkan pada tanggal 8 Januari 2013, dimana KPU mengumumkan 10 partai sebagai peserta Pemilu 2014. Dalam perkembangan berikutnya, keputusan KPU tersebut digugat oleh beberapa partai politik yang tidak lolos verifikasi ke Pengadilan Tata Usaha Negara, namun hanya ada dua partai yang dikabulkan gugatannya oleh PTUN yaitu Partai Bulan Bintang pada tanggal 18 Maret 2013 dan Partai Keadilan dan Persatuan Indonesia pada tanggal 25 Maret 2013. KPU mengabulkan putusan PTUN tersebut dan menetapkan kedua partai tersebut menjadi peserta Pemilu Legislatif 2014.

Berikut daftar 12 partai politik nasional peserta Pemilihan Umum Legislatif 2014 beserta nomor urutnya:

1. Partai NasDem,

2. Partai Kebangkitan Bangsa,

3. Partai Keadilan Sejahtera,

4. Partai Demokrasi Indonesia,

5. Partai Golongan Karya,

6. Partai Gerakan Indonesia Raya,

7. Partai Demokrat,

8. Partai Amanat Nasional,

9. Partai Persatuan Pembangunan, 10.Partai Hati Nurani Rakyat.

11.Partai Bulan Bintang,

12.Partai Keadilan dan Persatuan Indonesia.

Pada tanggal 10 Maret 2013, sepuluh partai politik yang gagal dalam verifikasi administrasi menyatakan bergabung dengan salah satu partai yang lolos menjadi peserta yaitu Partai Hati Nurani Rakyat antara lain Partai Kedaulatan, Partai Republika Nusantara (RepublikaN), Partai Nasional Republik (Nasrep), Partai Indonesia Sejahtera (PIS), Partai Pemuda Indonesia (PPI), Partai Kongres, Partai Damai Sejahtera (PDS), Partai Peduli Rakyat Nasional (PPRN), Partai 
Demokrasi Pembaruan (PDP), Partai Penegak Demokrasi Indonesia (PPDI). Perubahan peraturan; Dalam UU Nomor 8 Tahun Tahun 2012, pada awalnya ditetapkan bahwa ambang batas parlemen sebesar 3,5\% juga berlaku untuk DPRD. Akan tetapi, setelah Putusan Mahkamah Konstitusi No. 52/PUU-X/2012 maka ambang batas 3,5\% tersebut hanya berlaku untuk DPR dan ditiadakan untuk DPRD.

Peserta pemilihan umum anggota DPRD adalah partai politik yang sama dengan peserta pemilihan umum anggota DPR, kecuali khusus untuk Provinsi Aceh ditambah dengan partai politik lokal sesuai dengan Undang-Undang Pemerintahan Aceh dan Nota Kesepahaman Helsinki 2005. Berikut adalah daftar 3 partai politik lokal yang ditetapkan oleh Komite Independen Pemilihan Aceh sebagai peserta pemilihan umum anggota DPRD di Aceh beserta nomor urutnya.

1. Partai damai Aceh,

2. Partai Nasional Aceh,

3. Partai Aceh

Daerah pemilihan Pemilihan Umum Anggota DPR adalah provinsi atau gabungan kabupaten / kota dalam 1 provinsi, dengan total 77 daerah pemilihan. Jumlah kursi untuk setiap daerah pemilihan berkisar antara 3-10 kursi. Penentuan besarnya daerah pemilihan disesuaikan dengan jumlah penduduk di daerah tersebut.

\begin{tabular}{|c|l|c|c|}
\hline $\begin{array}{c}\text { No } \\
\text { Urut }\end{array}$ & \multicolumn{1}{|c|}{$\begin{array}{c}\text { Nama } \\
\text { Partai }\end{array}$} & $\begin{array}{c}\text { Jumlah } \\
\text { Suara }\end{array}$ & $\begin{array}{c}\text { Jumlah } \\
\text { Kursi }\end{array}$ \\
\hline 1. & $\begin{array}{l}\text { Partai Nasional } \\
\text { Demokrat }\end{array}$ & 8402812 & 35 \\
\hline 2. & $\begin{array}{l}\text { Partai Kebangkitan } \\
\text { Bangsa }\end{array}$ & 11298957 & 47 \\
\hline
\end{tabular}

\begin{tabular}{|c|l|c|c|}
\hline 3. & $\begin{array}{l}\text { Partai Keadilan } \\
\text { Sejahtera }\end{array}$ & 8480204 & 40 \\
\hline 4. & $\begin{array}{l}\text { Partai Demokrasi } \\
\text { Indonesia } \\
\text { Perjuangan }\end{array}$ & 23681471 & 109 \\
\hline 5. & $\begin{array}{l}\text { Partai Golongan } \\
\text { Karya }\end{array}$ & 18432312 & 91 \\
\hline 6. & $\begin{array}{l}\text { Partai Gerakan } \\
\text { Indonesia Raya }\end{array}$ & 14760371 & 73 \\
\hline 7. & Partai Demokrat & 12728913 & 61 \\
\hline 8. & $\begin{array}{l}\text { Partai Amanat } \\
\text { Nasional }\end{array}$ & 9481621 & 49 \\
\hline 9. & $\begin{array}{l}\text { Partai Persatuan } \\
\text { Pembangunan }\end{array}$ & 8157488 & 39 \\
\hline 10. & $\begin{array}{l}\text { Partai Hati Nurani } \\
\text { Rakyat }\end{array}$ & 6579498 & 16 \\
\hline 14. & $\begin{array}{l}\text { Partai Bulan } \\
\text { Bintang }\end{array}$ & 1825750 & 0 \\
\hline 15. & $\begin{array}{l}\text { Partai Keadilan } \\
\text { dan Persatuan } \\
\text { Indonesia }\end{array}$ & 1143094 & 0 \\
\hline
\end{tabular}

Berdasarkan keseluruhan uraian di atas maka dapat diketahui bahwa pengaturan pembatasan partai politik peserta pemilihan umum dalam perspektif demokrasi dalam UndangUndang Nomor 8 Tahun 2012 tentang Pemilihan Umum Anggota DPR, DPD, dan DPRD Perwakilan Daerah mengisryaratkan Ambang batas 3,5 persen berlaku menyeluruh dari pemilihan DPR, DPD, DPRD (provinsi, kabupaten dan kota), hal ini tentunya akan melahirkan beberapa masalah yang akan terjadi. Pasca Putusan Mahkamah Konstitusi No. 52/PUU-X/2012 maka ambang batas 3,5\% tersebut hanya berlaku untuk DPR dan ditiadakan untuk DPRD.

\footnotetext{
Korelasi Pembatasan Partai Politik Peserta Pemilihan Umum Dalam Undang-Undang Nomor 8 Tahun 2012 Tentang Pemilihan Umum
} 
Terhadap Hak Konsitusional Dalam Undang-

\section{Undang Dasar 1945}

Dalam demokrasi, partai politik merupakan pilar utama (bukan kedua atau ketiga), karena pucuk kendali roda pemerintahan ada di tangan eksekutif, yaitu presiden dan wakil presiden. Sebagaimana dirumuskan dirumuskan dalam UUD 1945 Pasal 6A ayat (2), bahwa calon presiden dan calon wakil presiden diusulkan oleh partai politik atau gabungan partai politik. Artinya hak itu secara eksklusif hanya partai politik yang disebut UUD 1945 diberikan kepada partai politik.

Karena itulah, semua demokrasi membutuhkan partai politik yang kuat dan mapan guna menyalurkan berbagai tuntutan warganya, memerintah demi kemaslahatan umum serta memenuhi kebutuhan dasar masyarakat. ${ }^{3}$ Sangat rasional argumentasinya jika upaya penguatan partai politik dibangun oleh kesadaran bahwa partai politik merupakan pilar yang perlu dan bahkan sangat penting untuk pembangunan demokrasi suatu bangsa. jadi, derajat pelembagaan partai politik itu sangat menentukan kualitas demokratisasi kehidupan politik suatu negara. ${ }^{4}$

Partai, politik, Pemilihan umum dan demokrasi adalah satu kesatuan yang saling berkaitan sebagai suatu sistem demokrasi. Namun demikian, apakah pembatasan partai politik peserta pemilihan umum dalam Undang-Undang Nomor 8 Tahun 2012 Tentang Pemilihan Umum melanggar hak konsitusional dalam Undang-Undang Dasar 1945. Hal inipun telah di uji dua kali ke Mahkamah Konstitusi.

Sabastian Salang, 2007, Potret Partai Politik di Indonesia, Asesmen Terhadap Kelembagaan, Kiprah, dan Sistem Kepartaian, Forum Politisi-Friedrich Naumann Stiftung, Jakarta, hal. 3
Pemohon yang terdiri dari beberapa partai politik mendalilkan bahwa, berdasarkan Pasal 28, Pasal 28C ayat (2), Pasal 28D ayat (1), Pasa128E ayat (3), Pasal $28 \mathrm{H}$ ayat (2) dan Pasal 281 ayat (2) UUD 1945, secara konstitusional setiap orang telah diberikan hak yang sangat mendasar, berupa kemerdekaan berserikat, berkumpul, mengeluarkan pendapat, memperjuangkan haknya secara kolektif, tanpa diskriminatif atas dasar apapun juga, bersamaan kedudukannya di depan hukum tanpa ada kecualinya, untuk membangun masyarakat, bangsa dan negara. Maka atas dasar hakhak konstitusional itulah para Pemohon, mendirikan partai politik dan telah memenuhi persyaratan, sesuai dengan Undang-Undang Nomor 31 Tahun 2002 tentang Partai Politik. Dengan diberlakukannya Pasal 9 ayat (1) dan ayat (2) Undang-Undang Nomor 12 Tahun 2003 tentang Pemilihan Umum, yang pada pokoknya menyatakan, bahwa yang dapat mengikuti pemilu yang akan datang adalah Partai Politik yang memperoleh suara minimal $3 \%$ dari jumlah kursi DPR. Oleh karena para Pemohon hanya memperoleh suara rata-rata kurang dari $3 \%$ dari jumlah kursi DPR, maka para Pemohon telah dirugikan hak konstitusionalnya, sebagaimana yang dimaksud dengan Pasal 22E ayat (3) UUD 1945, karena tidak dapat mengikuti Pemilu tahun 2009 yang akan datang.

Majelis Hakim Mahkamah Konstitusi dalam Perkara No. 16/PUU-V/2007 menyatakan bahwa ketentuan electoral threshold, antara lain bertujuan agar terbangun sistem multi partai sederhana (the

${ }^{4}$ Ibid. , hal. 3 
multiple simple party system), guna mewujudkan tujuan kemasyarakatan dan, kenegaraan yang berwawasan kebangsaan agar tercipta sistem pemerintahan yang stabil, juga ketentuan tersebut dapat digunakan sebagai pengukuran (parameter) legitimasi dukungan public terhadap partai politik, yang pada gilirannya masyarakat diberikan hak dan/atau kesempatan untuk memilih partai politik yang memiliki kapabilitas memadai. ${ }^{5}$

Disisi lain ketentuan tersebut juga memberikan kesempatan yang sama terhadap partai politik lain (baru) yang telah memenuhi syarat-syarat sebagaimana diatur dalam UndangUndang Partai Politik maupun Undang-Undang Pemilu, untuk mengikuti tahapan penyelenggaraan pemilihan umum guna memilih anggota Dewan Perwakilan Rakyat maupun Dewan Perwakilan Rakyat Daerah. Setiap warga negara diberikan hak yang sama untuk ikut serta di dalam pemerintahan dengan tanpa kecualinya (non diskriminatif), para Pemohon (13 partai politik) walupun tidak dapat mengikuti pemilihan umum berikutnya, tetapi tetap berhak untuk memajukan dirinya dalam memperjuangkan haknya secara kolektif untuk membangun masyarakat, bangsa, dan negaranya, yaitu dengan memaksimalkan peran dan fungsi partai politik itu sendiri, sebagaimana dijamin oleh ketentuan Pasal 27 ayat (1) dan Pasal 28C ayat (2) Undang-Undang Dasar Negara Republik Indonesia Tahun 1945.

Selain itu, ketentuan yang mengatur tentang batasan suara minimal yang harus didapat oleh sebuah partai politik (electoral threshold), untuk dapat megikuti pemilihan umum berikutnya, tidaklah serta merta dianggap sebagai perlakuan maupun pembatasan yang bersifat diskriminatif sepanjang pembatasan atau pembedaan yang dilakukan tidak didasarkan atas agama, suku, ras, etnik, kelompok golongan, status sosial, status ekonomi, jenis kelamin, bahasa dan keyakinan politik [vide Pasal 1 ayat (3) Undang-Undang Nomor 39 Tahun 1999 tentang Hak Masi Manusia, maupun Pasal 2 International Covenant on Civil and Political Rights]; Sehingga ketentuan yang mengatur tentang batasan suara minimal yang harus didapat oleh sebuah partai politik (electoral threshold) untuk dapat mengikuti pemilihan umum berikutnya, sebagaimana diatur dalam Pasal 9 ayat (1) dan ayat (2) UU Pemilu, tidak dapat dipandang secara serta merta dianggap telah bertentangan dengan Undang-Undang Dasar Negara Republik Indonesia Tahun 1945, karena pilihan sistem yang demikian merupakan pilihan kebijakan (legal policy) yang tidak dapat diuji, kecuali dilakukan secara sewenang-wenang (willekeur) dan melampaui kewenangan pembuat undang- undang (detournement de pouvoir).

Pembatasan terhadap partai politik untuk dapat mengikuti pemilihan umum berikutnya, menurut hemat Pemerintah telah sesuai dengan ketentuan Pasal 28J ayat (2) Undang-Undang Dasar Negara Republik Indonesia Tahun 1945, selain diatur dengan undang-undang, juga pembatasan tersebut adalah dalam rangka perlindungan dan pemenuhan hak asasi setiap orang (termasuk para Pemohon sebagai partai politik), selain itu pembatasan tersebut juga tidak bertentangan dengan norma-norma agama, 
kesusilaan, ketertiban umum maupun norma hukum yang berlaku.

Ketentuan tentang ET sudah dikenal sejak Pemilu 1999 yang tercantum dalam UndangUndang Nomor 3 Tahun 1999 tentang Pemilihan Umum yang kemudian diadopsi lagi dalam UU Nomor 12 Tahun 2003 tentang Pemilu, yang menaikkan ET dari 2\% (dua persen) menjadi 3\% (tiga persen), sehingga para Pemohon seharusnya sudah sangat memahami sejak dini bahwa ketentuan tentang ET tersebut memang merupakan pilihan kebijakan dari pembentuk undang-undang dalam rangka membangun suatu sistem multipartai sederhana di Indonesia. Menurut Mahkamah, kebijakan hukum (legal policy) di bidang kepartaian dan pemilu tersebut bersifat objektif, dalam arti sebagai seleksi alamiah dan demokratis untuk menyederhanakan sistem multipartai yang hidup kembali di Indonesia di era reformasi, setelah dianutnya sistem tiga partai pada era Orde Baru melalui penggabungan partai yang dipaksakan. Dalam hal ini, di antara para Pemohon bahkan ada yang ikut menentukan besaran ET tersebut, dan secara keseluruhan para Pemohon dengan mengikuti Pemilu 2004 berarti secara sadar sudah menerima adanya ketentuan tentang ET dalam UU Pemilu.

Banyak negara pada umumnya yang dianut bukan ET sebagai syarat untuk ikut pemilu berikutnya, melainkan parliamentary threshold (PT) yang membatasi suatu partai politik untuk dapat mendudukkan wakilnya di parlemen dengan syarat perolehan jumlah persentasi tertentu (misal $5 \%$ di Jerman). Akan tetapi, apakah akan memilih model ET ataukah PT, hal itu adalah masalah pilihan kebijakan dalam rangka membangun sistem kepartaian dan sistem perwakilan yang kuat dalam kehidupan ketatanegaraan dan politik melalui cara-cara yang demokratis dan konstitusional. Dari perspektif HAM sebagaimana didalilkan oleh para Pemohon, ketentuan yang tercantum dalam Pasal 9 ayat (1) dan ayat (2) UU Pemilu tidak mempengaruhi hak untuk berserikat dan berkumpul, termasuk hak untuk mendirikan partai politik, serta tidak ada unsur yang bersifat diskriminatif, sehingga ketentuan dalam pasal tersebut tidak bertentangan dengan hak asasi manusia. Berdasarkan hal tersebut, Amar Putusan No. 16/PUU-V/2007 menyatakan bahwa, dengan mengingat Pasal 56 ayat (5) Undang-Undang Nomor 24 Tahun 2003 tentang Mahkamah Konstitusi (LNRI Tahun 2003 Nomor 98, TLNRI Nomor 4316);

Mengadili:

Menyatakan permohonan para Pemohon ditolak;

Undang-undang No. 8 tahun 2012 tentang pemilu Anggota DPR, DPD, dan DPRD. Undangundang ini mengatur secara lebih spesifik tentang tujuan dari penyelanggaraan pemilu. Penyelenggaraan pemilu dimaksudkan untuk memilih anggota Dewan Perwakilan Rakyat dan Dewan Perwakilan Rakyat Daerah sebagai penyalur aspirasi politik rakyat serta anggota Dewan Perwakilan Daerah sebagai penyalur aspirasi keanekaragaman daerah sebagaimana diamanatkan dalam Pasal 22E ayat (2) Undang-Undang Dasar Negara Republik Indonesia Tahun 1945.

Pasal 208 UU 8/2012 dan Penjelasannya bertujuan untuk penyederhanaan kepartaian secara alamiah. Namun demikian, dari sudut substansi, ketentuan tersebut tidak mengako- 
modasi semangat persatuan dalam keberagaman. Ketentuan tersebut berpotensi menghalanghalangi aspirasi politik di tingkat daerah, padahal terdapat kemungkinan adanya partai politik yang tidak mencapai PT secara nasional sehingga tidak mendapatkan kursi di DPR, namun di daerahdaerah, baik di tingkat provinsi atau kabupaten/kota, partai politik tersebut memperoleh suara signifikan yang mengakibatkan diperolehnya kursi di lembaga perwakilan masing-masing daerah tersebut. Bahkan secara ekstrim dimungkinkan adanya partai politik yang secara nasional tidak memenuhi PT 3,5\%, namun menang mutlak di daerah tertentu. Hal demikian akan menyebabkan calon anggota DPRD yang akhirnya duduk di DPRD bukanlah calon anggota DPRD yang seharusnya jika merunut pada perolehan suaranya, atau dengan kata lain, calon anggota DPRD yang akhirnya menjadi anggota DPRD tersebut tidak merepresentasikan suara pemilih di daerahnya. Politik hukum sebagaimana yang ditentukan dalam Pasal 208 UU 8/2012 dan Penjelasannya tersebut justru bertentangan dengan kebhinnekaan dan kekhasan aspirasi politik yang beragam di setiap daerah.

Pemberlakuan PT secara nasional yang mempunyai akibat hukum pada hilangnya kursikursi partai politik yang tidak memiliki kursi di DPR namun partai politik bersangkutan memenuhi ketentuan bilangan pembagi pemilih di daerah dan menjadikan kursi-kursi tersebut dimiliki partai politik lain yang sebenarnya tidak memenuhi bilangan pembagi pemilih namun memiliki kursi di DPR, justru bertentangan dengan kedaulatan rakyat, hak politik, dan rasionalitas, sehingga bertentangan pula dengan tujuan pemilihan umum itu sendiri yaitu untuk memilih wakil rakyat mulai dari tingkat pusat hingga daerah.

Mahkamah Konstitusi menyatakan bahwa mahkamah juga menilai sekiranya PT 3,5\% diberlakukan secara bertingkat, masing-masing 3,5\% untuk DPR, DPRD provinsi, dan DPRD kabupaten/kota, dapat menimbulkan kemungkinan tidak ada satu pun partai politik peserta Pemilu di suatu daerah (provinsi atau kabupaten/kota) yang memenuhi PT 3,5\% sehingga tidak ada satupun anggota partai politik yang dapat menduduki kursi DPRD. Hal ini mungkin terjadi jika diasumsikan partai politik peserta Pemilu berjumlah 30 partai politik dan suara terbagi rata sehingga maksimal tiap-tiap partai politik peserta Pemilu hanya memperoleh maksimal 3,3\% suara. Selain itu, terdapat pula kemungkinan di suatu daerah hanya ada satu partai politik yang memenuhi PT 3,5\% sehingga hanya ada satu partai politik yang menduduki seluruh kursi di DPRD atau sekurangkurangnya banyak kursi yang tidak terisi. Hal itu justru bertentangan dengan ketentuan konstitusi yang menghendaki Pemilu untuk memilih anggota DPR dan DPRD, yang ternyata tidak tercapai karena kursi tidak terbagi habis, atau akan terjadi hanya satu partai politik yang duduk di DPRD yang dengan demikian tidak sejalan dengan konstitusi;

Menimbang bahwa berdasarkan pertimbangan tersebut di atas, menurut Mahkamah, permohonan Pemohon sepanjang mengenai frasa "DPRD Provinsi, dan DPRD kabupaten/kota" dalam Pasal 208 UU 8/2012 beralasan hukum. Dengan demikian, ketentuan PT 3,5\% hanya berlaku untuk kursi DPR dan tidak mempunyai akibat hukum terhadap penentuan/penghitungan 
perolehan kursi partai politik di DPRD provinsi maupun di DPRD kabupaten/kota; ${ }^{6}$

Berdasarkan hal tersebut, maka dapat diketahui bahwa konsep pembatasan peserta pemilu memang dibutuhkan sebagai eksistensi partai politik. Pembatasan peserta pemilu melalui sistem ambang batas dalam Undang Nomor 8 Tahun 2012 Tentang Pemilihan Umum melanggar sebagian hak konstitusi yang ada dalam Pasal 28, Pasal 28C ayat (2), Pasal 28D ayat (1), Pasal 28E ayat (3), Pasal $28 \mathrm{H}$ ayat (2) dan Pasal 281 ayat (2) UUD 1945. Ketentuan Pasal 208 UU 8/2012 dan Penjelasannya bertujuan untuk penyederhanaan kepartaian secara alamiah. Namun demikian, dari sudut substansi, ketentuan tersebut tidak mengakomodasi semangat persatuan dalam keberagaman, sehingga menurut Putusan Mahkamah Konstitusi No. 52/PUU-X/2012 ketentuan PT 3,5\% hanya berlaku untuk kursi DPR dan tidak mempunyai akibat hukum terhadap penentuan/penghitungan perolehan kursi partai politik di DPRD provinsi maupun di DPRD kabupaten/kota.

\section{PENUTUP}

\section{Kesimpulan}

Berdasarkan hasil peneltian dan pembahasan yang dilakukan oleh penulis, maka dapat diambil suatu simulan sebagai berikut: Pertama, Pengaturan pembatasan partai politik peserta pemilihan umum dalam perspektif demokrasi dalam Undang-Undang Nomor 8 Tahun 2012 tentang Pemilihan Umum Anggota DPR, DPD, dan DPRD diatur dalam Pasal 8 ayat (1),
Pasal 8 ayat (2) dan Pasal 208 Undang-Undang Nomor 8 Tahun 2012 tentang Pemilihan Umum Anggota DPR, DPD, dan DPRD. Pengaturan keharusan memenuhi ambang batas perolehan suara sekurang-kurangnya 3,5\% (tiga koma lima persen) dari jumlah suara sah secara nasional untuk diikutkan dalam penentuan perolehan kursi anggota DPR, DPRD provinsi, dan DPRD kabupaten/kota melanggar hak demokrasi. Dengan demikian Paska Putusan Mahkamah Konstitusi No. 52/PUU-X/2012, Pasal 208 UndangUndang Nomor 8 Tahun 2012 tentang Pemilihan Umum Anggota Dewan Perwakilan Rakyat, Dewan Perwakilan Daerah, dan Dewan Perwakilan Rakyat Daerah sepanjang frasa "DPRD provinsi, dan DPRD kabupaten/kota" tidak mempunyai kekuatan hukum mengikat, dengan demikian hanya mengikat DPR saja; Kedua, pembatasan peserta pemilu melalui sistem ambang batas dalam Undang Nomor 8 Tahun 2012 Tentang Pemilihan Umum melanggar sebagian hak konstitusi yang ada dalam Pasal 28, Pasal 28C ayat (2), Pasal 28D ayat (1), Pasal 28E ayat (3), Pasal 28H ayat (2) dan Pasal 281 ayat (2) UUD 1945. Ketentuan Pasal 208 UU 8/2012 dan Penjelasannya bertujuan untuk penyederhanaan kepartaian secara alamiah. Namun demikian, dari sudut substansi, ketentuan tersebut tidak mengakomodasi semangat persatuan dalam keberagaman, sehingga menurut Putusan Mahkamah Konstitusi No. 52/PUU-X/2012 ketentuan PT 3,5\% hanya berlaku untuk kursi DPR dan tidak mempunyai akibat hukum terhadap penentuan/penghitungan perolehan kursi partai

\footnotetext{
${ }^{6}$ Putusan Mahkamah Konstitusi No. 52/PUU-X/2012 hal. 99
} 
politik di DPRD provinsi maupun di DPRD kabupaten/kota.

\section{Saran}

Pertama, sebaiknya ambang batas kepesertaan pemilu sebanyak 3,5\% untuk DPR perlu dikaji kembali. Kedua, Pemerintah eksekutif dan DPR sebaiknya mengkaji dan membentuk aturan mengenai sistem multi partai dan penyederhanaannya melalui metode alternatif.

\section{DAFTAR PUSTAKA}

\section{Buku}

Asshiddiqie, Jimly. 2006. Kemerdekaan Berserrikat. Pembubaran Partai Politik dan Mahkamah Konstitusi. Konstitusi Press. Jakarta.

Azhary, Tahir Muhammad. 1994. Negara Hukum Suatu Studi tentang Prinsip-prinsipnya Dilihat dari segi Hukum Islam. Implementasinya pada periode Negara madinah dan Masa Kini. Cetakan kedua. Prenada Media. Jakarta.

Budiarjo, Miriam. 2000. Pengantar IImu Politik. Gramedia. Jakarta. 